\title{
Are urban areas suitable for thermophilic and xerothermic bee species (Hymenoptera: Apoidea: Apiformes)?
}

\author{
Weronika BANASZAK-CIBICKA \\ Institute of Zoology, Poznań University of Life Sciences, Wojska Polskiego 71C, 60-625 Poznań, Poland
}

Received 18 February 2013 - Revised 19 July 2013 - Accepted 2 August 2013

\begin{abstract}
One of the most noticeable features of the urban climate is the air temperature increase in the city compared to the surrounding area ("urban heat island"). This study focused on the influence of urban climate on the occurrence of thermophilic and xerothermic bee species from southern Europe. The southern species were relatively common among the bee assemblages observed within the area of Poznan, Poland. In Central Europe, these species are observed only in isolated xerothermic localities and, as shown by the present study, in the urban areas. Cities enable some of the Southern European species of bees to move north. During this study, species that are rare in Poland were also observed. In that respect, the study also draws attention to the importance of urban areas in preserving biodiversity.
\end{abstract}

\section{Apoidea / bees / urbanization / urban heat island / Poznań}

\section{INTRODUCTION}

Urbanization results in a number of longlasting environmental changes, which may result in limiting the occurrence of animals and plants (Savard et al. 2000). However, for some species, the city may provide opportunities for development that cannot be found elsewhere (Luniak et al. 1990; Møller et al. 2009). A vast number of ecological niches, high food availability, heterogeneous environment, as well as the specific urban climate, ensure highly convenient conditions for numerous species. One of the most noticeable features of the urban climate is that air temperature in the city is higher than the temperature in the surrounding area (Oke 1973).

This phenomenon is commonly referred to as the urban heat island effect. The temperature

Corresponding author: W. Banaszak-Cibicka, banaszak@up.poznan.pl

Manuscript editor: Stan Schneider increase depends on the size of the city; however, the difference can reach $12{ }^{\circ} \mathrm{C}$ on clear days, or 1$2{ }^{\circ} \mathrm{C}$ in yearly mean temperature. A variety of factors have been attributed to be the cause of the urban heat island effect. Removal of vegetation, construction of buildings, roads, pavements and other human transformations of the natural environment, together with direct heat generation from human activity, are known to cause the temperatures of urban areas to rise above those of the surrounding rural areas.

Recently, climate change has been a subject of broad discussion (Houghton 2004; Rosenzweig et al. 2008). Climate change refers to any changes of climate over time, both for natural reasons and as a result of human activity (IPCC 2007). There are also numerous studies on the influence of these changes on the distribution and phenology of different insect species (Hickling et al. 2005; Musolin and Saulich 2012); however, the vast majority of those studies are on butterflies (Burton 1998; Parmesan et al. 1999; Sparks et al. 2006), 
dragonflies (Hickling et al. 2005) and true bugs (Nau and Brooke 2003; Yukawa et al. 2007). At the same time, only a few studies have addressed the influence of climate change on Hymenoptera (Sparks et al. 2010; Tryjanowski et al. 2010).

Interest in the urban fauna started in the 1970s, when the first studies were conducted (Ebeling 1975; Pisarski and Trojan 1976; Banaszak et al. 1978; Czechowski 1979; Luniak 1980; Bornkamm et al. 1982; Sukopp et al. 1982; Zapparoli 1997). This is a current subject of research, which is confirmed by the regular appearance of studies on urban fauna including pollinating insects (Germanie and Wakeling 2001; McIntyre and Hostetler 2001; Zerbe et al. 2003; McFrederick and Le Buhn 2006; Matteson et al. 2008; Indykiewicz et al. 2011). A general pattern established during the last decades shows differences between urban and surrounding rural areas (Møller et al. 2012). Nevertheless, there is still a lack of basic knowledge of the ecology of urban ecosystems.

Bees are a unique group of insects because their total dependence on food derived from flowers makes them very important pollinators. They are vital both for human economics and nature. Determining the changes in the natural resources of bees, which occur under the influence of anthropogenic pressure, and understanding the ecological processes underlying them are currently focal points of apidology.

There are almost no studies that show how specific urban climate conditions affect the insect fauna. Cities constitute heat islands, and their warmer and drier climates provide proper conditions for a number of thermophilic and xerothermic species from southern Europe. Thermophilic and xerothermic species are more or less closely associated with warm and dry habitats. Thus, the meaning largely overlaps with the attributive meaning of 'steppe'. Thermophilic and xerothermic bee species tend to occur only in dry and warm sites, such as banks of valleys and sandy slopes with favorable exposure (Kuntze 1931). Those bees prefer open habitats, which is more abundant in steppes and dry meadows than in wooded habitats. They inhabit much of the areas surrounding the Mediterranean Sea and the Black
Sea. The majority of the regions with Mediterranean climates have relatively mild winters and very warm, dry summers. Temperatures during winter only occasionally fall below freezing point. In the summer, the temperatures range from mild to very hot, depending on the distance from a large body of water, elevation, and latitude. The southern bee species could move to the area of Poland from the east along the Vistula, from the west along the Torun-Eberswalde Proglacial Valley, or from the south across the Moravian Gate (Banaszak 2006).

In Central Europe, these species are observed only in isolated xerothermic localities. Cities enable some of the southern European species of bees to move north ensuring proper nesting locations, because the urban areas are substantially warmer and drier than the surrounding areas. The aim of this study was to investigate the urban bee fauna in terms of zoogeography and to evaluate whether or not thermophilic and xerothermic species find suitable conditions for bee nesting and offspring development in the cities.

\section{MATERIALS AND METHODS}

\subsection{Study area}

Poznań $\left(52^{\circ} 25^{\prime} \mathrm{N}, 16^{\circ} 58^{\prime} \mathrm{E}\right)$ is a city of 560,000 inhabitants with an area of $261 \mathrm{~km}^{2}$. Poznan is one of the oldest cities in Poland. The climate is shaped by polar air masses originating from the Atlantic Ocean. Continental polar air masses originating from middle Russia exert lesser influence. Additionally, cold arctic air masses and equatorial air masses also reach Poznań (Woś 1994). Average annual temperature in Poznań between 1984 and 2000 was $8.5^{\circ} \mathrm{C}$.

The urban heat island range calculated based on average annual temperatures in the 1990s now covers the entire city. Positive $\Delta \mathrm{T}$ (change in temperature $\Delta \mathrm{T}=\mathrm{T}$ in the city $-\mathrm{T}$ control outside the city) values are observed not only within urban developments, mansion flats or blocks of congregated flats, but also in villa districts and the outskirts with a substantial contribution of green areas. The intensity of the heat island effect decreases as one moves from the center 
$\left(\Delta \mathrm{T}=0.81{ }^{\circ} \mathrm{C}\right)$ to the estates in the outskirts $\left(\Delta \mathrm{T}=0.06{ }^{\circ} \mathrm{C}\right)$. The temperature decreases in all directions outside the compact developments in the city center (Farat et al. 2006).

Wind loses approximately $30 \%$ of speed within the city from wind outside the city (Farat et al. 2006). The relative humidity in the city center is lower than in the outskirts. Furthermore, compared to areas outside the city, the average precipitation increases by $10-30 \%$, snow falls less frequently and the snow cover melts faster (Farat 1996).

Woś (2006) reported a trend the last 50 years of early occurrence and prolongation of thermal spring and summer. Additionally, the observations in the Adam Mickiewicz University Botanical Garden indicate early occurrence of spring and delayed occurrence of autumn as well as their prolongation (Sparks et al. 2011). These results suggest increases in the length of the growing season. However, responses of plants to the changing climate were species-specific. Thus, the transitions from winter into spring and from autumn into winter are becoming less clearly defined (Sparks et al. 2011).

Bees were sampled on eight sites $(50 \times 50 \mathrm{~m})$ located within the urban matrix representing a wide spectrum of urban environments. Study plots were along an urbanization gradient from areas of concentrated settlement of tenement houses in the strict city center, through sparse housing estates, areas of detached houses to big urban green areas. The study sites were located from 250 to $4,900 \mathrm{~m}$ from the city centre. A more detailed description of the habitat characteristics is given in Banaszak-Cibicka and Żmihorski (2012).

\subsection{Bees sampling}

The study of bees within Poznan was conducted between 2006 and 2010. Yellow Möericke traps were used to catch the specimens, as they had previously been used successfully for the collection of bees in urban fragments (Banaszak 2004a). Within each site, four yellow pan traps were used. At each location, traps were placed 25-50 m apart. Insects were collected from traps every 7-10 days from April to September. Direct searching along transects, which covered the most attractive resource patches, was also conducted at each site. On transects, bees were netted by hand twice each month from April to September. Within the plots, the surveyor was not restricted to the fixed transect line, instead the surveyor walked within the plot at a slow speed among any potentially attractive resource patches and collected bees during an observational period of 30 min. Pan traps remain an effective sampling technique when flowers are scarce or when targeting particular species that are easily trapped. Thus, to avoid potential trapping biases and to characterise the local bee fauna, there is the need to supplement pan trapping protocols with netting (Roulston et al. 2007). Species that could not be identified in the field were kept for later identification.

All collected individual bees were pinned in the laboratory, sorted and identified to species level. Zoogeographical traits for each species were compiled from primary literature, catalogues, and reference works (Banaszak 1993; Scheuchl 1995; SchmidEgger and Scheuchl 1997; Banaszak et al. 2001; Pesenko et al. 2000; Pawlikowski and Celary 2003). The definitions of geographical ranges for particular species were adopted in accordance with Kostrowicki (1953) and Banaszak et al. (2006).

The obtained results were compared with the joint list of bee species captured in Poznań by other researchers. The first studies on bees within the area of Poznan come from the 1970s and contain information on bees occurring in large urban green areas (Banaszak 1973; Wójtowski and Szymaś 1973), in the Botanical Garden (Banaszak 1976) and in community gardens (Wójtowski and Feliszek 1977). There are also a number of studies on single species observed in Poznań (Banaszak 1969, 1976; Ruszkowski 1969).

The bee fauna observed within Poznań was compared with the bee fauna of one of the bigger green areas in the vicinity of the city-Wielkopolska National Park (WNP) (Cierzniak 2003). The park was established in 1957, $15 \mathrm{~km}$ south of Poznań. Currently the park's area is 7,584 ha. Additionally, a buffer zone was formed around the park whose area, together with the park, is 14,840 ha. The collected data were also compared with the regional fauna of the Wielkopolsko-Kujawska Lowland (Banaszak 2010), which is part of the Polish Lowland occupying 6,863,000 ha located in western Poland. Important cities of the Wielkopolsko-Kujawska Lowland are Poznań, Bydgoszcz, and Torun. The southern bee species was also compared to two other 
well-examined cities in Poland-Bydgoszcz (Banaszak 2008) and Łódź (Kowalczyk et al. 2008).

Data on bees in the Wielkopolska National Park, the Wielkopolsko-Kujawska Lowland and those from Bydgoszcz and Łódź were collected over long periods with similar methods which makes them comparable to those from Poznań. This level of faunal identification offers a unique opportunity to compare the bee fauna of Poznan with that of neighbouring areas and with fauna of other cities.

\subsection{Statistical analysis}

A contingency table was applied for estimating the significance of differences in the contribution of southern species to the fauna of the city of Poznan and the fauna of the WNP. A calculation was presented as a result of a chi-squared test, with information on the number of the southern species and the number of other species in the local bee communities.

The similarities of bee communities in Poznan and WPN and Poznań and other cities (Bydgoszcz, Łodź) were compared using the Sorensen-Dice coefficient (Sorensen 1948).

The occurrence of southern species of different bees in three cities (Poznań, Bydgoszcz, Łódź), was compared based on binary data matrix ( 0 , absence; 1 , presence) using the Kendall Tau-b correlation index.

\section{RESULTS}

In the course of the studies conducted in Poznań, I observed 41 species of bees that have not been seen in Poznań before. A detailed list of species can be found in previous studies (Banaszak-Cibicka and Banaszak 2011a; Banaszak-Cibicka and Żmihorski 2012). Among the 41 species, 22 are widely spread, mainly western and eastern Palearctic species (19), European-Asian species (1), European-Siberian species (1) and Holarctic species (1). Additionally, 6 European species were captured. The remaining 13 species of bees are southern species: Submediterranean (5), Subpontic (2), PonticMediterranean (3), Pontic-Submediterranean (1), Subpontic-Mediterranean (2).
Five species among the southern species are rare in Poland (Table I):

Megachile pilidens Alfken, 1923

Andrena florea Fabricius, 1793

Andrena mitis Schmiedeknecht, 1838

Andrena congruens Schmiedeknecht, 1883

Osmia mustelina Gerstaecker, 1869

Based on our studies and those of other authors, 206 bee species have so far been identified in Poznań (Banaszak-Cibicka and Banaszak 2011a). Seventeen zoogeographical elements have been distinguished among these species (Table II). The vast majority comprises widely distributed species - Geopolitical, Holarctic, Palearctic (including West Palearctic and East Palearctic) and Siberian-European — which jointly comprise nearly $64 \%$ of the bee fauna of Poznań. Southern species - Submediterranean, Subpontic, Pontic-Mediterranean, Subpontic-Mediterranean and Subpontic-Mediterranean-jointly comprise $15.7 \%$ of the bee fauna of Poznan.

Comparison of the contribution of southern species to the bees of Poznan (15.7\%) and that of the WNP (9 \%) showed statistically significant differences $\left(\chi^{2}=4.067 ; p=0.043\right)$. The similarity coefficient between Poznań and WPN was 0.751 .

The occurrence of southern species in the bee communities of different Polish cities was also compared. The percentage of southern species is similar for all three surveyed cities (Poznań$15.7 \%$, Bydgoszcz-12.8\%, Łódź-16.2\%). However, there was no significant correlation between the southern bee species composition in those cities (Table III). Thus, each of the cities in question supports specific southern fauna. The similarity coefficient between Poznań and Bydgoszcz was 0.763 and between Poznań and Łódź was 0.753 .

\section{DISCUSSION}

My previous studies (Banaszak-Cibicka 2009; Banaszak-Cibicka and Banaszak 2011a; Banaszak-Cibicka and Żmihorski 2012) as well as those by other authors show that, contrary to popular belief, cities are important habitats for a 
Table I. Description of the rare southern bee species observed in Poznań

\begin{tabular}{|c|c|c|c|c|}
\hline Species & Distribution & Localities in Poland & WNP & WKL \\
\hline $\begin{array}{l}\text { Megachile } \\
\text { pilidens }\end{array}$ & $\begin{array}{l}\text { A Pontic-Mediterranean species. } \\
\text { Its range extends to the Ukraine } \\
\text { (Podole), the Czech Republic, } \\
\text { Slovakia, and Germany (Baden, } \\
\text { Saxony, Thuringia and } \\
\text { Brandenburg) (Banaszak } \\
\text { et al. 2001). }\end{array}$ & $\begin{array}{l}\text { Known to inhabit rare localities } \\
\text { in Sandomierz Basin and Lower } \\
\text { Silesia, Poland (Banaszak et al. } \\
\text { 2001). Its localities in the lower } \\
\text { Vistula valley are its northernmost } \\
\text { records (Banaszak 2008) }\end{array}$ & - & + \\
\hline $\begin{array}{l}\text { Andrena } \\
\text { florea }\end{array}$ & $\begin{array}{l}\text { A Pontic-Mediterranean species. } \\
\text { It can be found in Southern and } \\
\text { Central Europe, Northern Africa } \\
\text { and Asia (Dylewska 2000). }\end{array}$ & $\begin{array}{l}\text { Very rare, classified as an } \\
\text { endangered species in Poland } \\
\text { (Banaszak 2004b). Observed in } \\
\text { different parts of Poland to date, } \\
\text { now in large quantities or even } \\
\text { masses in Bydgoszcz (Banaszak, } \\
\text { personal information). }\end{array}$ & - & + \\
\hline $\begin{array}{l}\text { Andrena } \\
\text { mitis }\end{array}$ & $\begin{array}{l}\text { Found in Southern and Central } \\
\text { Europe and in Turkey } \\
\text { (Osytschnjuk et al. 2005). }\end{array}$ & $\begin{array}{l}\text { Has been observed in Silesia, Cracow } \\
\text { and near Tarnów (Dylewska 2000). }\end{array}$ & - & + \\
\hline $\begin{array}{l}\text { Andrena } \\
\text { congruens }\end{array}$ & $\begin{array}{l}\text { From Southern and Central Europe, } \\
\text { Northern Africa and Asia Minor } \\
\text { (Dylewska 2000). }\end{array}$ & $\begin{array}{l}\text { In Poland, it has been observed } \\
\text { in the south part of the country } \\
\text { (Dylewska 2000) }\end{array}$ & - & - \\
\hline Osmia mustelina & $\begin{array}{l}\text { A Pontic-Mediterranean species. } \\
\text { Its range extends to the Central } \\
\text { Europe, South-Eastern Europe, } \\
\text { Caucasus, Iran, Sicily (Banaszak } \\
\text { et al. 2001). }\end{array}$ & $\begin{array}{l}\text { In Poland, it occurs in few } \\
\text { localities in different parts } \\
\text { of the country (Banaszak } \\
\text { et al. 2001). }\end{array}$ & - & + \\
\hline
\end{tabular}

Dashes $(-)$ indicate absence of species; $(+)$ indicate presence of species

WNP Wielkopolska National Park (data from Cierzniak 2003), WKL Wielkopolsko-Kujawska Lowland (data from Banaszak 1982)

considerable number of bee species (Saure 1996; Zapparoli 1997; Cane 2005). So far, 206 bee species have been identified in Poznań (BanaszakCibicka and Banaszak 2011a). This number accounts for $43 \%$ of the bee fauna of Poland (Banaszak 2004b) and as much as $79 \%$ of the species recorded from the region-WielkopolskaKujawy Lowland (Banaszak 1982).

One needs to bear in mind that the vast majority of bee species live in environments heavily influenced by humans, which are often profoundly transformed. Urban development results in a diminishment of natural and seminatural habitats. The quality of residual habitats for bees is also expected to be adversely affected by various forms of pollution. Therefore, it is extremely important to learn about the impact of anthropogenic environments on bee assemblages.
On the other hand, the WNP is one of the largest green areas located in the nearest vicinity of Poznań. Currently, the area of the park and its buffer zone is 14,840 ha. The WNP has been found to support 225 bee species (Cierzniak 2003), i.e. $48 \%$ of all Polish bees. Of the 206 species found within the Poznań city boundaries to date, 162 have also been recorded in WNP, and the similarity coefficient between Poznań and WPN was 0.751. On the other hand, the park supports an additional 63 bee species that have not been found in the city (Banaszak-Cibicka and Banaszak 2011b). The bee fauna of Poznań is relatively rich compared to the natural bee faunas of the region. Most of the abundant species in the WNP are also among those most abundant in the city. Even some species natural to forests are often found in the city in parkland areas or forested green spaces. Rarely, several forest-associated 
Table II. Zoogeographical elements in the bee fauna of Poznań, Wielkopolsko-Kujawska Lowland (data from Banaszak 1982) and the Wielkopolska National Park (data from Cierzniak 2003)

\begin{tabular}{|c|c|c|c|c|c|c|}
\hline \multirow[t]{2}{*}{ Elements } & \multicolumn{2}{|c|}{ Poznań } & \multicolumn{2}{|c|}{ Wielkopolsko-Kujawska Lowland } & \multicolumn{2}{|c|}{ WNP } \\
\hline & $n$ & $\%$ & $n$ & $\%$ & $n$ & $\%$ \\
\hline Geopolitical & 1 & 0.5 & 1 & 0.4 & 1 & 0.4 \\
\hline Holarctic & 10 & 5.0 & 3 & 1.1 & 14 & 6.2 \\
\hline Palearctic & 50 & 24.6 & 37 & 14.3 & 56 & 24.8 \\
\hline West Palearctic & 42 & 20.6 & 31 & 12 & 47 & 20.8 \\
\hline East Palearctic & 3 & 1.3 & 0 & 0 & 1 & 0.4 \\
\hline Siberian-European & 23 & 11.3 & 30 & 11.6 & 27 & 12 \\
\hline Caucasian-European & 11 & 5.4 & 0 & 0 & 10 & 4.4 \\
\hline European & 24 & 11.8 & 61 & 23.5 & 39 & 17.3 \\
\hline Northern-Central European & 4 & 2.0 & 27 & 10.4 & 7 & 3.1 \\
\hline West European & 1 & 0.5 & 0 & 0 & 1 & 0.4 \\
\hline Boreal-alpine & 1 & 0.5 & 2 & 0.8 & 1 & 0.4 \\
\hline Central European & 1 & 0.5 & 0 & 0 & 0 & 0 \\
\hline Submediterranean & 13 & 6.4 & 26 & 10 & 4 & 1.7 \\
\hline Subpontic & 3 & 1.4 & 15 & 5.8 & 5 & 2.2 \\
\hline Pontic-Mediterranean & 9 & 4.4 & 17 & 6.6 & 8 & 3.5 \\
\hline Subpontic-Mediterranean & 1 & 0.5 & 0 & 0 & 0 & 0 \\
\hline Subpontic-mediterranean & 6 & 3.0 & 0 & 0 & 4 & 1.7 \\
\hline
\end{tabular}

$n$ number of species, \% percentage contribution to the entire fauna

species dominant in WNP are seen in Poznań boundaries. They allow for the colonization by (Banaszak-Cibicka and Banaszak 2011b).

The high diversity of bees in cities is related to a large number of microenvironments within their species with different habitat requirements (Savard et al. 2000). This spatial heterogeneity can support even greater species richness than

Table III. Results of Kendall Tau-b correlation analysis between the occurrence of particular southern species in Poznań, Bydgoszcz (data from Banaszak 2008) and Łódź (data from Kowalczyk et al. 2008)

\begin{tabular}{|c|c|c|c|c|c|}
\hline & & & \multicolumn{3}{|c|}{ Correlations } \\
\hline & & & Poznań & Bydgoszcz & Łódź \\
\hline \multirow[t]{9}{*}{ Kendall Tau-b } & \multirow[t]{3}{*}{ Poznań } & Correlation coefficient & 1.000 & .049 & -.025 \\
\hline & & Significance (bilateral) & . & .728 & .857 \\
\hline & & $n$ & 52 & 52 & 52 \\
\hline & \multirow[t]{3}{*}{ Bydgoszcz } & Correlation coefficient & .049 & 1.000 & -.149 \\
\hline & & Significance (bilateral) & .728 & . & .287 \\
\hline & & $n$ & 52 & 52 & 52 \\
\hline & \multirow[t]{3}{*}{ Łódź } & Correlation coefficient & -.025 & -.149 & 1.000 \\
\hline & & Significance (bilateral) & .857 & .287 & . \\
\hline & & $n$ & 52 & 52 & 52 \\
\hline
\end{tabular}


surrounding natural areas (Cierzniak 2003). Urban areas also include flower-rich green areas that can provide forage for a high diversity of wild bees (Frankie et al. 2005). Cities may also contain appropriate sites for nesting (McFrederick and Le Buhn 2006). Also, several abiotic factors differ between urban and rural areas, temperature being one of the most important. The specific urban conditions may affect the colonization of cities by species with southern ranges. Warmer and drier urban climates provide living conditions appropriate for xerophilic and thermophilic bee species from Southern Europe. In Central Europe, these species are only found in isolated xerothermic localities and, as this research shows, in urban areas. Thus, cities enable certain southern species of bees to extend their ranges northwards.

The study shows that, for certain southern species that are rare in Poland, urban areas present favorable conditions for development. This may be due to many factors, e.g., the availability of nesting sites or appropriate floral resources and, what is the most probable, specific climate conditions. The rare species observed in Poznań, including Megachile pilidens, Andrena florea, Andrena mitis, Andrena congruens and Osmia mustelina, have not been observed in the nearby WNP so far. All of them, except for Andrena congruens, were found in thermophilic, xerothermic grasslands in the lower Vistula valley in the Wielkopolsko-Kujawska Lowland (Banaszak et al. 2006). In recent years, these rare species have also been observed in Bydgoszcz and Łódź (Banaszak 2008; Kowalczyk et al. 2008). Their presence in the city may be related to suitable thermal conditions. This result shows that some species can find more suitable living conditions in cities than in protected areas.

These findings agree with the results of other European studies of urban derelict sites which show that cities not only provide habitats for eurytopic (widely distributed) species in the surrounding urban landscape but they are also important for conserving locally rare species (Kegel 1990), and in some cases, national rarities and stenotopic (able to adapt only to a narrow range of environmental conditions) species, which are colonists from semi-natural habitats such as open and dry grasslands (Eversham et al. 1996). It has been estimated that over $50 \%$ of British rare aculeate Hymenoptera and over $35 \%$ of British rare and scarce carabid species have been recorded from anthropogenic habitats (Eversham et al. 1996; Gibson 1998; Kadas 2006).

The urban environment presents higher temperatures compared to suburban areas. Thus, it seems to be a favorable habitat for southern fauna. Seventeen zoogeographical elements were represented among bee species in Poznań. Most of the bees are widely distributed species and comprise nearly $64 \%$ of all species found. The situation is similar in the WNP, where those species comprise nearly $65 \%$ of the bee fauna (Cierzniak 2003). Southern species-Submediterranean, Subpontic, Pontic-Mediterranean, SubponticMediterranean and Subpontic-Mediterraneanjointly comprise $15.7 \%$ of the bee fauna of Poznań. This is a large number compared to the WNP, where southern species comprise only $9 \%$ of the bee community. The low number of southern species in the WNP is related to the scarcity of xerothermic environments in its area. Moreover, these environments are continuously becoming overgrown with shrubs and trees (Banaszak et al. 2003). On the other hand, southern species of bees found in the entire Wielkopolsko-Kujawska Lowland comprise 22.4\% of the fauna due to the ability to thrive in the many available xerothermic environments. Xerothermic grasslands in the lower Vistula valley - being miniatures of Ukrainian steppes in floristic termsare refuges for many southern bee species. The insects could have moved to this area from the east along the Vistula, from the west along the TorunEberswalde Proglacial Valley, or from the south across the Moravian Gate (Banaszak et al. 2006). Apart from the large number of xerothermic environments, the vast area of the WielkopolskoKujawska Lowland also contributes to the wide diversity of species, including the southern ones (Banaszak 1982). However, it needs to be emphasized that despite its considerably smaller area compared to the Wielkopolsko-Kujawska Lowland and factors that can negatively affect the occurrence 
of bees (e.g., moving, soil turning, development), Poznań harbors a relatively high number of southern species. Many authors write about urban areas being attractive for thermophilic and xerothermic species but, at the same time, only a few studies have addressed the influence of urban areas on insects. Kollár and Hrubík (2009), investigating mining insects in West Slovak area, recorded a high increase of a non-indigenous thermophilic species number from the Mediterranean in urban areas, while others claimed that no southern species of pollinating insects (Eremeeva and Sushchev 2005) and ants (Vepsäläinen et al. 2008) during studies were recorded.

Apart from Poznań, Bydgoszcz (Banaszak 2008) and Łódź (Kowalczyk et al. 2008) are currently the cities with the best known bee fauna in Poland. The three cities support similar numbers of bee species: Poznań-206, Bydgoszcz-195, and Łódź-203 (Banaszak-Cibicka and Banaszak 2011a). The similarity coefficient between Poznań and Bydgoszcz was 0.763 and between Poznań and Łódź was 0.753 .

The contribution of southern species to the bee assemblages in the analyzed cities is similar (Poznań-15.7 \%, Bydgoszcz-12.8 \%, Łódź$16.2 \%)$. Therefore, this research indicates some general pattern of the influence of urban areas on bees. However, studies show a faunal distinctness between the cities in question. The cities differ with regard to the composition of southern species that can be found within their boundaries (Table II). This uniqueness stems probably from the geographical location of the cities.

Thus, the study underlines the impact of urban climate on a specific bee community. It shows that, by providing bees with proper conditions for development, the urban environment enables certain southern species to move northwards. At the same time, the study indicates the relevance of urban areas to biological diversity preservation as they may serve as a habitat not only for widely distributed species but also for rare species with specific requirements. It shows that, for some species, cities can be even a better place for living than protected areas.
Since urbanization is an ever on-going process and questions related to the impact of urban climate on bee assemblages are still widely unexplored, further detailed research is required to investigate the influence of urban areas on these exceptionally beneficial insects.

\section{ACKNOWLEDGMENTS}

I would like to thank Piotr Tryjanowski for statistical advice and valuable comments on the manuscript. I am grateful to Józef Banaszak and Aleksandra Łangowska for the critical reading of the manuscript. Anonymous reviewers provided helpful comments on the previous version of the text. I acknowledge the gracious hospitality of all landowners for allowing me to collect data on their property.

\section{OPEN ACCESS}

This article is distributed under the terms of the Creative Commons Attribution License which permits any use, distribution, and reproduction in any medium, provided the original author(s) and the source are credited.

Les zones urbaines peuvent-elles convenir aux espèces d'abeilles thermophiles et xérothermiques (Hymenoptera: Apoidea: Apiformes)?

Apoidea / abeilles / urbanisation / îlot de chaleur urbain / Pologne

Sind urbane Gebiete für thermophile und xerotherme Bienenarten (Hymenoptera: Apoidea: Apiformes) geeignet?

Apoidea / Bienen / Urbanisierung / städtische Wärmeinsel / Poznań

\section{REFERENCES}

Banaszak, J. (1969) Spostrzeżenia nad fauna błonkówek (Hymenoptera) glinianych ścian zabudowań wiejskich w środkowej Wielkopolsce. Bad. Fizjogr. Pol. Zach., B-biologia 23, 231-233

Banaszak, J. (1973) Pszczołowate (Apoidea) okolic Poznania. Bad. Fizjogr. Pol. Zach., B-biologia 26, 33-78 
Banaszak, J. (1976) Pszczoły (Hymenoptera: Apoidea) Ogrodu Botanicznego w Poznaniu. Bad. Fizjogr. Pol. Zach., C-zoologia 29, 71-85

Banaszak, J. (1982) Pszczoły (Apoidea, Hymenoptera) Niziny Wielkopolsko-Kujawskiej. Fragm. Faun. 27(7), 75-92

Banaszak, J (1993) Trzmiele Polski. Wyd. Uczelniane WSP w Bydgoszczy, Bydgoszcz

Banaszak, J. (2004a) Z badań nad owadami zapylającymi w Bydgoszczy (Hymenoptera, Apoidea). In: Indykiewicz, P., Barczak, T. (eds.) Fauna miast Europy Środkowej 21. wieku. Wyd, pp. 225-233. LOGO, Bydgoszcz

Banaszak, J. (2004b) Pszczoły (Apidae). In: Bogdanowicz, W., Chudzicka, Z., Pilipiuk, I., Skibińska, E. (eds.) Fauna Polski wykaz gatunków, pp. 358-362. Muzeum i Instytut Zoologii PAN, Warszawa

Banaszak, J. (2006) Bees of xerothermic swards in the lower Vistula valley: diversity and zoogeographic analyses (Hymenoptera: Apoidea: Apiformes). Pol. J. Entomol. 75, 105-154

Banaszak, J. (2008) Fauna pszczół (Hymenoptera: Apoidea: Apiformes) Bydgoszczy, in: Indykiewicz, P., Barczak, T. (eds.), Fauna miast. Ochronić różnorodność biotyczną w miastach, SAR „Pomorze", Bydgoszcz, pp. 234-245

Banaszak, J. (2010) The persistence of and changes in a bee fauna over the last century: case of Wielkopolska-Kujawy Lowland in western Poland (Hymenoptera: Apoidea, Apiformes). Pol. J. Entomol. 79(4), 367-409

Banaszak, J., Czechowski, W., Pisarski, B., Skibińska, E. (1978) Owady społeczne w środowisku zurbanizowanym. Kosmos, Seria A-Biologia 2(251), $173-180$

Banaszak, J., Romasenko, L., Cierzniak, T. (2001) Klucze do oznaczania owadów Polski. Cz. XXIV Błonkówki-Hymenoptera. Zeszyt 68f-Podrodzina Megachilinae. Polskie Tow Entomol, Toruń

Banaszak, J., Cierzniak, T., Ratyńska, H. (2003) Local changes in populations of wild bees (Hymenoptera: Apoidea) 20 years later. Pol. J. Entomol. 72, 261282

Banaszak, J., Cierzniak, T., Kriger, R., Wendzonka, J. (2006) Bees of xerothermic swards in the lower Vistula valley: diversity and zoogeographic analyses (Hymenoptera: Apoidea: Apiformes). Pol. J. Entomol. 75, $105-154$

Banaszak-Cibicka, W. (2009) Specificity of city bee fauna (Hymenoptera: Apoidea: Apiformes) on the example of Poznań, Poland. PhD dissertation, Adam Mickiewicz University, Poznan

Banaszak-Cibicka, W., Banaszak, J. (2011a) Pollinating insects of cities (Hymenoptera: Apoidea: Apiformes). Part I. Fauna of Poznań in comparison with bees of other polish cities, in: Indykiewicz, P., Jerzak, L., Böhner, J., Kavanagh, B. (eds.) Urban fauna. Studies of animal biology, ecology and conservation in European cities, pp. 227-236

Banaszak-Cibicka, W., Banaszak, J. (2011b) Pollinating insects of cities (Hymenoptera: Apoidea: Apiformes). Part II. Fauna of cities in comparison with bees in natural habitats, in: Indykiewicz, P., Jerzak, L., Böhner, J., Kavanagh, B. (eds.) Urban fauna. Studies of animal biology, ecology and conservation in European cities, pp. 237-250

Banaszak-Cibicka, W., Żmihorski, M. (2012) Wild bees along an urban gradient: winners \& losers. J. Insect Conserv. 16, 331-343

Bornkamm, R., Lee, J.A., Seaward, M.R.D. (1982) Urban ecology. Blackwell, Oxford

Burton, J.F. (1998) The apparent effects of climate changes since 1850 on European Lepidoptera. Mem. Soc. R. Entomol. Belg. 38, 125-144

Cane, J.H. (2005) Pollination potential of the bee Osmia aglaia for cultivated red raspberries and blackberries (Rubus: Rosaceae). Hortic. Sci. 40, 1705-1708

Cierzniak, T. (2003) Changes in the bee fauna (Apoidea) of the Wielkopolska National Park over the last half century. Fragm. Faun. 46, 151-170

Czechowski, W. (1979) Urban woodland areas as the refuge of invertebrate fauna. Bull. Acad. Pol. Sci. Ser. Biol. 27, 179-182

Dylewska, M. (2000) Klucze do oznaczania owadów Polski. Cz. XXIV Błonkówki-Hymenoptera. Zeszyt 68d-Andrenidae. Polskie Tow. Entomol. Toruń

Ebeling, W. (1975) Urban entomology. Univ. Calif. Div. Agric. Sci, Berkeley

Eremeeva, N.I., Sushchev, D.V. (2005) Structural changes in the Fauna of Pollinating insects in urban landscapes. Russ. J. Ecol. 36(4), 259-265

Eversham, B.C., Roy, D.B., Telfer, M.G. (1996) Urban, industrial and other manmade sites as analogues of natural habitats for Carabidae. Ann. Zool. Fenn. 33, $149-156$

Farat, R. (1996) Klimat Poznania, in: Kurek, R. (ed.), Środowisko naturalne miasta Poznania. Urząd Miejski w Poznaniu Wydział Ochr. Środ. Poznań

Farat, R., Koczorowska, R., Zawadzki, T., Pijewska, I. (2006) Specyfika warunków termicznych i wiatrowych aglomeracji poznańskiej. Instytut Meteorologii i Gospodarki Wodnej Odział w Poznaniu-typescript

Frankie, G., Thorp, R.W., Schindler, M., Hernandez, J., Ertter, B., Rizzardi, M. (2005) Ecological patterns of bees and their host ornamental flowers in two northern California cities. J. Kans. Entomol. Soc. 78, 227-246

Germanie, S.S., Wakeling, B.F. (2001) Lizard species distributors and habitat occupation along an Urban gradient in Tucson, Arizona. USA. Biol. Conserv. 97, 229-237

Gibson, C.W.D. (1998) Brownfield: Red data. The values artificial habitats have for uncommon inver- 
tebrates. English Nature Research Reports No. 273. English Nature, Peterborough

Hickling, R., Roy, D.B., Hill, J.K., Thomas, C.D. (2005) A northward shift of range margins in British Odonata. Glob. Change Biol. 11, 502-506

Houghton, J. (2004) Global warming. The complete briefing. 3rd edn. Cambridge University Press, Cambridge

Indykiewicz, P., Jerzak, L., Böhner, J., Kavanagh, B. (2011) Urban fauna. Studies of animal biology, ecology and conservation in European cities. Bydgoszcz

IPCC (Intergovernmental Panel on Climate Change). Climate change 2007: The physical science basis. summary for policymakers. Contribution of working group I to the Fourth Assessment Report of the Intergovernmental Panel on Climate Change (IPCC), Geneva, Switzerland

Kadas, G. (2006) Rare invertebrates colonizing Green roofs in London. Urban Habitats 4(1), 66-86

Kegel, B. (1990) The distribution of carabid beetles in the urban area of Berlin. In: Stork, N.E. (ed.) The role of ground beetles in ecological and environmental studies, pp. 325-329. Intercept, Andover

Kollár, J., Hrubík, P. (2009) The mining species on woody plants of urban environments in the West Slovak area. Acta Entomol. Serbica 14(1), 83-91

Kostrowicki, A.S. (1953) Studia nad fauną motyli wzgórz kserotermicznych nad dolną Nidą. Fragm. Faun. Musei Zool. Polonici 6(16), 356

Kowalczyk, J.K., Szczepko, K., Kurzac, T. (2008) Stan poznania pszczół (Hymenoptera, Apoidea, Apiformes) Łodzi, in: Indykiewicz, P., Jerzak, L., Barczak T. (eds.) Fauna miast; Ochronić różnorodność biotyczną w miastach. SAR „Pomorze", Bydgoszcz, pp. 246-252

Kuntze, R. (1931) Studya porównawcze nad fauna kserotermiczna na Podolu, w Brandenburgii. Austrii i Szwajcarii. Arch. Tow. Nauk. Lwów 5(6), 1-81

Luniak, M. (1980) Birds of allotment garden in Warsaw. Acta Orn., Warszawa 17, 298-319

Luniak, M., Mulsow, R., Walasz, K. (1990) Urbanization of the European blackbird: expansion and adaptations of urban population. In: Luniak, M. (ed.) Urban ecological studies in Central and Eastern Europe, pp. 87-199. Ossolineum, Warsaw

Matteson, K.C., Ascher, J.S., Langellotto, G.A. (2008) Bee richness and abundance in New York City Urban gardens. Ann. Entomol. Soc. Am. 101(1), $140-150$

McFrederick, Q.S., Le Buhn, G. (2006) Are urban parks refuges for bumble bees Bombus spp. (Hymenoptera: Apoidea)? Biol. Conserv. 129, 372-382

McIntyre, N.E., Hostetler, M.E. (2001) Effects of urban land use on pollinator (Hymenoptera: Apoidea) communities in a desert metropolis. Basic Appl. Ecol. 2, 209-218
Møller, A.P., Erritzøe, J., Karadas, F. (2009) Levels of antioxidants in rural and urban birds and their consequences. Oecologia 163, 35-45

Møller, A.P., Diaz, M., Flensted-Jensen, E., Grim, T., Ibáñez-Âlamo, J.D., Jokimäki, J., Mänd, R., Markó, G., Tryjanowski, P. (2012) High urban population density of birds reflects their timing of urbanization. Oecologia 170, 867-875

Musolin, D.L., Saulich, A.K. (2012) Responses of insects to the current climate changes: from physiology and behavior to range shifts. Entomol. Rev. 92(7), 715-740

Nau, B.S., Brooke, S.E. (2003) The contrasting range expansion of two species of Deraeocoris (Hemiptera- Heteroptera: Miridae) in South-East England. Br. J. Entomol. Nat. Hist. 16, 44-45

Oke, T.R. (1973) City size and urban heat island. Atmos. Environ. 7, 769-779

Osytschnjuk, A.Z., Romasenko, L., Banaszak, J., Cierzniak, T. (2005) Andreninae of the Central and Eastern Palaearctic. Part 1. Polish Entomol. Soc. Poznań, Bydgoszcz

Parmesan, C., Ryrholm, N., Stefanescu, C. (1999) Poleward shifts in geographical ranges of butterfly species associated with regional warming. Nature 399, 579-583

Pawlikowski, T., Celary, W. (2003) Klucze do oznaczania owadów Polski. Cz. XXIV BłonkówkiHymenoptera. Zeszyt 68a. Pszczołowate-Apidae. Wstęp i podrodzina lepiarkowate-Colletidae. Polskie Tow. Entomol., Toruń

Pesenko, Y.A., Banaszak, J., Radchenko, V.G., Cierzniak, T. (2000) Bees of the family Halictidae (excluding Sphecodes) of Poland: taxonomy, ecology, bionomics. Wyd. Uczeln. WSP, Bydgoszcz

Pisarski, B., Trojan, P. (1976) Zoocenozy obszarów zurbanizowanych. Wiad. Ekol. 22, 338-344

Rosenzweig, C., Karoly, D., Vicarelli, M. (2008) Attributing physical and biological impacts to anthropogenic climate change. Nature 453, 353-357

Roulston, T.H., Smith, S.A., Brewster, A.L. (2007) A comparison of pan trap and intensive net sampling techniques for documenting a bee (Hymenoptera: Apiformes) fauna. J. Kansas Entomol. 80(2), 179-181

Ruszkowski, A. (1969) Rośliny pokarmowe i znaczenie gospodarcze trzmieli z podrodzaju Subterraneobombus Vogt. Pamiętnik Puławski-Praca IUNG 37, 411-428

Saure, C. (1996) Urban habitats for bees: the example of the city of Berlin. [w:] A. Matheson, A. Buchmann, S.L. O'Tole, P. Westrich, I.H. Williams (red.) The conservation of bees. Academic, New York

Savard, J.P.L., Clergeau, P., Mennechez, G. (2000) Biodiversity concepts and urban ecosystems. Landsc. Urban. Plan. 48, 131-142

Scheuchl, E. (1995) Illustrierte Bestimmungstabellen der Wildbinen Deutschlands und Osterreichs 1: Anthophoridae. Eigenverlag, Velden 
Schmid-Egger, C., Scheuchl, E. (1997) Illustrierte Bestimmungstabellen der Wildbinen Deutschlands und Osterreichs 3: Andrenidae. Eigenverlag, Velden

Sorensen, T. (1948) A method of establishing groups of equal amplitude in plant sociology based on similarity of species content and its application to analyses of the vegetation on Danish commons. K. Dan. Vidensk Selsk. Skr. 5, 1-34

Sparks, T.H., Huber, K., Dennis, R.L.H. (2006) Complex phenological responses to climate warming trends? lessons from history. Eur. J. Entomol. 103, 379-386

Sparks, T.H., Langowska, A., Głazaczow, A., Wilkaniec, Z., Bieńkowska, M., Tryjanowski, P. (2010) Advances in the timing of spring clearing by the honeybee Apis mellifera in Poland. Ecol. Entomol. 35, 788-791

Sparks, T., Górska-Zajączkowska, M., Wójtowicz, W., Tryjanowski, P. (2011) Phenological changes and reduced seasonal synchrony as a consequence of a warming climate. Int. J. Biometeorol. 55, 447-453

Sukopp, H., Elvers, H., Mattes, H. (1982) Studies on urban ecology of Berlin (West). In: Pisarski, B. (ed.) Luniak, M, pp. 115-130. Animals in urban environment. Ossolineum, Wrocław

Tryjanowski, P., Pawlikowski, T., Pawlikowski, K., Banaszak-Cibicka, W., Sparks, T.H. (2010) Does climate influence phenological trends in social wasps (Hymenoptera: Vespinae) in Poland? Eur. J. Entomol. 107(2), 203-208
Vepsäläinen, K., Ikonen, H., Koivula, M.J. (2008) The structure of ant assemblages in an urban area of Helsinki, southern Finland. Ann. Zool. Fenn. 45, 109-127

Woś, A. (1994) Klimat Niziny Wielkopolskiej. Wyd. UAM, Poznań

Woś, A. (2006) Termiczne pory roku w Poznaniu w drugiej połowie XX wieku. In: Trepińska, J., Olecki, Z. (eds.) Klimatyczne aspekty środowiska geograficznego, pp. 117-126. Instytut Geografii i Gospodarki przestrzennej UJ, Kraków

Wójtowski, F., Szymaś, B. (1973) Dziko żyjące pszczołowate (Hym. Apoidea) terenów zieleni miejskiej Poznania. Roczniki Akad. Roln. w Poznaniu 66, 163-169

Wójtowski, F., Feliszek, H. (1977) Apidofauna zapylająca drzewa i krzewy owocowe w pracowniczych ogródkach działkowych Poznania. Roczniki Akad. Roln. w Poznaniu 94, 235-241

Yukawa, J., Kiritani, K., Gyoutoku, N. (2007) Distribution range shift of two allied species, Nezara viridula and $N$. antennata (Hemiptera: Pentatomidae), in Japan, possibly due to global warming. Appl. Entomol. Zool. 42, 205-215

Zapparoli, M. (1997) Urban development and insect biodiversity of the Rome area. Italy. Landsc Urban Plan. 38, 77-86

Zerbe, S., Maurer, U., Schmitz, S., Sukopp, H. (2003) Biodiversity in Berlin and its potential for nature conservation. Landsc. Urban. Plan. 62, 139-148 